\title{
Love and Revenge of Eben in Desire under the Elms: A Psychoanalytic Reading
}

\begin{abstract}
A.K.M. Aminur Rashid
Senior Lecturer in English, International University of Business Agriculture \& Technology, Dhaka, Bangladesh akmaminur.rashid@iubat.edu

Abstract: This paper draws on the story of Eben Cabot's love and revenge from a well-known American play, Desire under the Elms with a critique from the Freudian psychological interpretation of love and of revenge drive. The essay brings out the traumatic manifestation of vengeance and horror when Eben's love for his mother turns him into an avenger for taking a revenge on his father, Ephraim Cabot. As Eben thinks his mother is killed by his father, he gives his father a severe penalty by removing him with disowning his two elder brothers. In addition, he succeeds wooing her newly married step-mother, Abbie Putnam; and manages to sleep with her. After she gives birth to a baby, she herself smothers it only for Eben. When Abbie leaves the Cabot House and rushes with Eben, Eben's father feels utterly disgraced while Eben feels he avenges finally.
\end{abstract}

Keywords: O’Neil, Love, Sexuality, Revenge, Murder, Loneliness.

\section{INTRODUCTION}

Eugene Gladstone O'Neill was born on $16^{\text {th }}$ October 1888 in a hotel room in Broadway in New York. He wrote many famous plays such as Strange Interlude, Mourning Becomes Electra, The Long Voyage Home, In the Zone, and, Desire under the Elms. He has been the first American naturalist who, in his plays, manifested different modern ideas, and focused on a very particular kind of literary strategy. In addition, he portrayed very complex psychological human life in his literary works, such as, love, double game, conflict and revenge. These portrayals have been relevant in his presentation of symbolic figures, masks, delineation of inner tension, complexity, fragmented personalities and scenic effects. In this way, the readers can explore a psychologically disturbing world in its fullest. Literally, he went beyond the romantic theatrical display of the bohemian life of the American materialistic society, and rather portrayed a tragic reality in which his characters have been seen suffering from a sort of inner conflict, and mental dissatisfaction. John Gassner suggests that "his plays embodied the ideas and conflicts of the first half of the twentieth century, assimilated its advances in dramatic art and theatrical technique, and expressed its uneasy aspirations toward tragic insights and dramatic vision" (Gassner 6).

O'Neill's play, Desire under the Elms is seen to manifest the psychologically intensive and conflicting nature of Eben Cabot. He is the protagonist of the play, who impersonates an intensive feeling of inner tension regarding the death of his mother, whom he supposes to be killed by Ephraim Cabot, his father. Literally, O'Neil sketches of Ephraim Cabot being a person indifferent to his wife, and family that eventually creates a disintegration among him, and his wives. He also has problems with his sons for they, as he thinks, are soft in their treatment to people. Primarily, Eben, the youngest son, is found to be in conflict with his father that brings an ultimate failure in their relationship to each other. Out of an emotional deficiency, Ephraim's first two wives, as it can be reported from Simeon, Peter, and Eben's conversation, were deprived of his husband's love, and care. They were exploited, physically crushed, and left to a neglected life. Therefore, as arguments took place among the brothers, the mothers' deaths were caused by the workloads of Ephraim's household, which let grow anger in their sons' minds for their father. Specially, through the portrayal of Eben's hatred, the relationship crisis between the father, and sons come highlighted.

www.arjonline.org

Page 1 
As the novel's title implies, though absent, silent, and indifferent to the traumatic exposure of Ephraim's betrayal, the mothers - even they are dead- have still a very strong influence on the household, and on their children. O'Neil's remarkable use of symbolism delineates how two enormous elm branches symbolizing the sagging breasts of Eben's mother, tired, and get mingled with the house. It is like those two branches are regretting to Eben about his father's maltreatment to her, and cherish a desire for his punishment. Her presence is felt throughout the Cabot house by Eben, such as, in it's kitchen, parlor, and different other corners. In this way, O'Neil's sketch of Elms' branches in the play bears a significant symbol of women's influences on the house. Slowly, thinking about mother's unselfish love to his father, and of his father's lovelessness, Eben turns him to an avenger, and vows to take his revenge on his father. The playwright precisely concentrates on Eben's psychological development, and, thus depicts how he is torn between the feeling of love and of revenge. This is why the essay will be discussed from a psychoanalytical perspective, analyzing how Eben Cabot receives a traumatic shock at the loss of his mother, and plans to take revenge on his father. In fact, the psychoanalytic reading shall portray Eben's feeling of love toward his mother, and the feeling of revenge toward his father.

\section{A Psychoanalytic Reading of Eben Cabot's Drives}

Desire under the Elms can be analyzed as a criminal case study in which Eben Cabot, a man of twenty five, investigates the cause of the death of his mother, and resolves to punish the wrongdoer. As far as the theory of psychoanalysis is concerned, Eben manifests psychologically two different types of emotional drives in his nature - the love drive and the revenge or death drive. From Sigmund Freud's psychological interpretation, it can be understood that Eben's feeling of love and of revenge can be argued to represent two types of instinctual drives, which finally contribute to the formation of his mind. Moreover, Freud furthers this idea of the drives in Beyond the Pleasure Principle and Other Writings, where he claims:

On the basis of theoretical considerations underpinned by biology, we posited a death drive charged with the task of causing animate organisms to revert to an inanimate state, whereas Eros pursues the goal of maximizing the complexity of life- thereby of course preserving it- by an ever more catholic combination of the particles into which living matter had been fragmented. (130)

Eben's love drive can be explained as the internal formation of his mind; an abstract feeling, which naturally pours from the heart, but it is blended with the revenge drive, and becomes 'a special organ', as Freud thinks. Freud observes that "how drives of the two types connect, combine and blend with each other remains entirely unimaginable - but that such a thing happens, routinely and on a verge scale, is a postulate crucial to our whole framework of ideas" (Freud 131). Regarding the connection of the drives to each other, Freud suggests in Beyond the Pleasure Principle and Other Writings:

we can hypothesize that as a consequence of the fusion of unicellular elementary organisms into multicellular organisms, the death drive in the individual cell was successfully neutralized, and its destructive impulses diverted to the external world through the mediation of a special organ, to witt the musculature; the death drive accordingly now finds expression- though in all probability only in part- as a destruction drive directed against the external world and other organisms. (131)

Such diverse characteristics - love and revenge- as experienced by Eben can be analyzed in the light of psychoanalytic criticism. As it has been mentioned before, the distinct feelings of love, and of revenge are the two distinct aspects of Eben's psychic life. They signify a dynamic relation with Eben's real life action. Freud distinguishes these drives into sexual drive, or Eros and the death drive (Freud 130). He argues that sexual drive or Eros signifies a person's technique to gain self-preservation. On the other hand, Erich Fromm's comment on the term self-preservation can also be taken into account along with Freud. Fromm says that, "I have attempted 
to develop a revised theory of the drives and passions that motivate men's behavior in addition to those that serve his self-preservation" (Fromm 24). From Fromm's words, it is understood that the drives in a man are necessary for self-preservation. Similarly, the death drive, which drives Eben to be an avenger and to punish his father is needed for Eben's self-preservation because as Fromm claims "all of man's passions and cravings, whether normal, neorotic, or psychotic, attempt to solve his immanent dichotomy; and because it is vital for man to find a solution" (Fromm 25). Eben's immanent dichotomy is to appease his dead mother's soul by killing his father, and thus possess the properties his father owns.

In this way, Eben can bring a solution to his problems with his father. Eben does not kill his father at all, but plans to give severe punishment to his father than death. Fromm argues that man's power of thinking gives him a unique kind of strength to have a better solution. Eben thinks that he shall not kill his father. Eben thinks to leave him utterly lonely by taking everything from him. Such temperament of taking revenge can be interpreted to be Eben's inherent biological constitution that produces different solutions such as casting away his father to loneliness, possessing the farm, and his stepmother. As Eben suffers immensely from mental agony, he lets his father suffer more severely, and painfully. Fromm also suggests that "the nature or essence of man, then, as this theory conceives it, consists in nothing but the opposition inherent in man's biological constitution-an opposition that produces different solutions" (Fromm 26).

Therefore, in Eben both the feelings of love, and of revenge are intended to be the solutions of his biological, and mental needs. When the feeling of love he feels for his mother in his heart, it becomes dominant in his actions, and works accordingly, but when the feeling of revenge overcomes him looking at his father, then the feeling of revenge becomes dominant. In fact, Fromm revises Freud's understanding of the subject's drives, and claims that "the classic theory is that Freud tried to understand all human passions as being rooted in physiological or biological needs, and he made ingenuous theoretical constructions in order to uphold this position" (Fromm 28). Fromm believes that "the most powerful human drives are not those aimed at physical survival but those through which man seeks a solution of his existential dichotomy- namely, a goal for his life" (Fromm 28).

The love drive, and the death drive in Eben are the central theme in the play. Although the plot is simple, but the manifestation of Eben's feeling of love for his mother, and feeling of hate or revenge toward his father are intertwined, and become the sole root of Eben's internal conflict in his mind. That is why Eben remains dissatisfied with the life he is living in his house, and shows disobedience to his father. His dissatisfaction with his life, and his father becomes clearly visible in his first appearance in the play. When the reader opens the play, it describes his face being overcome with intense hatred for a person he dislikes. As the play progresses, it is known that he actually shows an active dislike for his father. So, hate draws off the curtain of the play to start, and draws on the curtain to end the play.

To define hatred, Willard Gaylin writes that "Hatred: The condition or state of relations in which one person hates another; the emotion or feeling of hate; active dislike, detestation; enmity, ill-will, malevolence" (Gaylin 21). Eben's love for his dead mother, and his hatred for his father cannot be compared to each other, but are binaries because his love for his mother is meant to be unification with her while his plan to kill his father signifies segregation from him. But Gaylin defines hatred as "a sustained emotion of rage that occupies an individual through much of his life, allowing him to feel delight in observing or inflicting suffering on the hated one" (Gaylin 34).

In the play, Eben, the hater, inflicts continuous suffering on his father, the hated one. The play reveals Eben's constant scheme of revenge on his father colored with threats, and fear. It ends with Eben's feeling of selfpreservation, and a solution to his conflict with his father. Eben attempts to leave his father in a world of extreme loneliness to die in it every day. For this, Eben is, at last, identified with the death drive, and finishes his mission, that leads him to what Freud terms 'self-preservation' and Fromm calls a 'solution'. When Eben looses his mother's affection, and love for his father, his love drive then takes on the death drive to punish his father.

American Research Journal of English and Literature

Page 3 


\section{EBEn's Loss of Love AND THE Motive of REVENGE}

O'Neil describes Eben being trapped in two emotional drives - love and revenge- because he is repeatedly failing to decide to take revenge on his father. O'Neill has discussed what is happening inside his mind. In particular, from his appearance in the opening scene of the play, the audience realizes that he has been suffering from a valuable loss for a long period of time, and is found confining himself to distance that discloses relationships have met disintegrations. This looks explicit in O'Neil's depiction of Eben showing "His face is well-formed, good-looking, but its expression is resentful and defensive. His defiant, dark eyes remind one of a wild animal's in captivity" and "he spites on the ground with intense disgust, turns and goes back into the house" (O'Neill 7). In the quotation, his resentfulness reminds the reader of the Freudian analysis of the psychic process of the sexual, and the destruction or death drives. Generally, the feeling of revenge in a person takes place when another person does wrong to him. Similarly, Eben experiences this feeling of revenge because he feels that his father does wrong to him distancing from his beloved mother by enslaving her to death.

As a consequence, Eben is filled with an impulse of hatred toward his father. Freud considers such impulse of hate as an opposite substitute to love. He reasons that "we might reasonably substitute the polarity of love and hate for the antithesis constituted by the two types of drives" (Freud 132). He adds that "whereas of course we have no problem showing how Eros is represented, it comes as quite a relief that we are now able to identify the destruction drive- which takes its lead from hate- as representing the highly elusive death drive" (Freud 132). Eben's intense anger- as it is perceived at the beginning of the play - reflects on the Freudian notion of the death drive. Soon - as the play proceeds on - this Freudian notion of the death drive becomes incredibly stronger in Eben. Eben's confidence to brand his father, the sole murderer to his mother, becomes evident in his asking to his brothers, "didn't he slave Maw t' death?" (0’Neill 11).

This question further introduces us with his father being a complete alien to them, and, at the same time opening the very regretful side of the familial bonds falling apart at that time in America. Fake beliefs, run for for success, and abuses on failing actually mark a tremendous impact on the families, and their relations breaking into pieces. Ephraim's pride on his success, and his so-called distance with his sons make a prime example. However, Eben's deep love for his mother is clearly perceived in his asking to his brother about his mother, and that ultimately paves the way to avenge his mother. Thus, the seed of the father-son conflict begins to bloom in the play. Eben plans to take away the house from his father at first, which he thinks shall be the starting step to his taking of revenge. He starts planning how he shall own his father's farmhouse, and, ultimately, finds a path to inflict on his father a worthy punishment. Eben realizes that, the way his father has separated him from his mother, he will also distance his father from the farm, which is the only loveliest possession, where he has spent fifty years of his life.

It is true that the farm is very close a possession to his father that he himself confesses to his newly married wife, Abbie Putnam: "ye kin read the years of my life in them walls" and adds that "it was all mine! When I thought o' that I didn't feel lonesome" (O'Neill 41). To put an end to his mission, Eben very knavishly structures his plan. He experiences a change of drive in him, that is to say, the drive of vengeance overcomes him. From the Freudian perspective "the transformation [from love to vengeance] is brought about through a reactive displacement of cathexis, whereby energy is withdrawn from the erotic impulse [for his mother], and added to the hostile one [against his father]" (Freud 134). The loss of love that he received from his mother can be argued to have caused a neurotic disorder to his mind. He tells that he has still contacts with her, who communicates, helps him doing household chores. He claims to his brothers that he can see, and talk to her. In fact, he fantasizes about his dead mother's being still alive, which gives a sign of fantasizing under neurosis. From the Freudian interpretation, his neurotic fantasy can be confirmed in his proclamation to his brothers that "me cookin'-doin' her work-that made me know her, suffer her sufferin'-she'd come back t' help-come back t' bile potatoes" (O'Neill 13). 
In addition, in the Freudian scholarship of neurosis, Eben looks becoming a neurotic patient, who recalls his relationship with his dead mother, who he considers to be his self-preservative one. Even after her death, he keeps his mother alive in his neurotic fantasy. Freud observes that "in the conflict which creates the neurosis, what are at stake are either solely libidinal interests or libidinal interests in intimate connections with selfpreservative ones" (Freud 422). He adds that "in a greater number of cases the neurosis is more autonomous and more independent of the interest of self-preservation and self-maintenance" (Freud 422). Moreover, Eben's neurotic condition can also remarkably be observed in his hallucinations when he says that "she still comes back-stands by the stove thar in the evenin'-she can't find nateral sleepin' an' restin' in peace. She can't git used t' bein free-even in her grave" (O'Neill 13). In this respect, his experiencing of neurotic behavior can be compared to demonic neurosis according to Freud's interpretation of psychoanalysis. Freud, in Art and Literature, shares one of his experiences he earned while giving the medical treatment to a patient called Christoph Haizmann, who was a painter, and had a demonological illness (Freud 421).

In Christoph's case, he was found talking to his father's ghost in his neurotic fantasy. Freud believed that Christoph needed to preserve his self, which was his material need, and that is why he took the ghost, which represented his father-figure. Freud admits that "nor would our painter's wretched situation in life have provoked a demonological neurosis in him if his material need had not intensified his longing for his father" (Freud 423). Eben's neurosis is also close to Christoph's case. Like him, Eben, also in his neurotic fantasy, claims that he talks to his mother's ghost. In this case, it is argued that Eben's too much attachment to his mother even after her death reveals his requirement to preserve his self, like the painter required. Literally, to discuss Eben's neurotic sentiment for his mother bears his loving her to a greater extent.

On the other hand, the presence of Eben's dead mother takes the audience to an another dimension of his psychic development too - the hate drive. He also feels that the presence of his mother's soul is not awe inspiring; rather it is reminding him of his unfinished task. It is Eben hypothetically concludes that his mother cannot sleep in comfort in her grave because his father still remains unpunished. Verily, Eben assures with vengeful passion to his brothers that "an' sooner'r later, I'll meddle. I'll say the thin's I didn't say then t' him! I'll yell 'em at the top o' my lungs. I'll see t' it my Maw gits some rest an' sleep in her grave!" ( $0^{\prime} N$ eill 13). Freud observes that in such cases of neurosis, the patients exhibit a kind of obsessional neurosis that can be caused by the dearest person the patient looses and, sometimes, as a consequence, the patient is obsessed by the dearest person's memory.

Freud further defines it in the following terms by explaining that "obsessional neurosis may be the most interesting and most rewarding object of scrutiny within the purview of psychoanalysis but as a problem it none the less remains unresolved" (Freud 180). From a general point of view, Eben's vow to avenge his mother turns to neurosis because he needs a feeling of quick justice through punishing the miscreant to pacify his ego. Until his mission is complete, Eben spares no chance of providing his father with the perception of alienation. This is due to the crisis of family tie between the father, and the son, and O'Neil also describes that it happens due to the lack of conscious intellect, and the rise of unconscious desires. The treatment Eben's mother received from Ephraim, representing a personality of unconscious desires, created a feeling of unwantedness, and fury in her. There was a serious lack of conscious intellect in Ephraim, because his character is as Doris Falk identifies him as "only an image of his own ego." Falk also condemns Cabot's "exploitive egotism," his pride, his "brutal lust" (Falk 94-98).

Such a deeply rooted intricacy between the father, and the mother can easily impact on their children's personalities. Like many other children, Eben had a special bond only with his mother. Ultimately, he inherits her personality, and temperament to a greater extent, and inherits nothing from his father's belief in hardness of life, and emotional dryness. Therefore, like his mother, Eben experiences the same lack of closeness with his father like once his mother experienced. Thus the duality between Ephraim, and Eben continues until Eben, neurotically, lets his father be completely solitary. The obsession of revenge that overcomes Eben does 
not consist instantly; rather Eben develops it at an early age. Freud describes in Beyond the Pleasure Principle and Other Writings that "moreover, the nethermost layer of every obsessional neurosis appears to consist of hysterical symptoms that were formed at a very early stage" (Freud 2003, 180). Freud relates this idea of obsessional neurosis to the patient's previously unscathed genital life, as he describes that "it became very clear that it was a specific impairment of the patient's previously unscathed genital life that created the conditions conducing to regression and the emergence of his obsessional neurosis" (Freud 181).

According to Michael P Levine, the denial of the mother's love to Eben is understood as a pleasure-denial law on him by his father who "as a primal father constituted himself as a primal sovereign" (Levine 280). Therefore, it is understood that the conflict between Eben, and his father results in its historical primal father-son conflict in which the fight takes place between a physically strong father, and a weak son on their particular issue of love, and of revenge. Ephraim's being physically strong is a sign of his power to which Eben finds himself weaker. Eben states that 'I'm gittin' stronger. I kin feel it growin' in me-growin' an' growin'-till it'll bust out-!" (O'Neill 14). John Henry Raleigh also pays attention to Ephraim, who is described as being "a great grotesque, a powerful buffoon ... an almost endearing old miser and lecher" (Raleigh 54). Raleigh continues that Ephraim "has an ego of monumental proportions and is, in fact, that very God he keeps referring to and calling upon. For what he really represents is pure power, physically and emotionally" (Raleigh 54). As characterized by fatherson conflict, Eben enters into a physical relationship with the village prostitute, Minnie, the scarlet woman in the village, who his father goes to have sex. Literally, through Eben's physical relationship with Minnie, Eben experiences to start showing some strength to violate of the law of rules created by his father. Added that having sex with Minnie his father had- Eben, for the first time, explores his stern, and vengeful disposition against his father in practice.

\section{Love And Revenge Result in Eben's Possession of the FARM}

As a part of the revenge scheme - full of hatred, and empty of richness in the Cabot relationships - Eben gives his full attention to how he can possess the farm solely. He knows that his two other step-brothers have their share in it. But Eben believes that the farm in which he lives is his dead mother's, and considers that his father steals it from her by murdering her. In fact, Eben, with proper planning, decides a way to take back the farm by removing his brothers at first. He confronts his brothers, and when they say that two-thirds of the farm belongs to them, Eben humps to his feet and retorts that “ye'hv no right! She wa'n't yewr Maw! It was her firm! Didn't he steal it from her? She's dead. It's my farm" (O'Neill 12). The unrealistic behavior that he displays to his brothers madly arises from his desire to avenge his father. Here the land is the owned material property Ephraim is indulgent in while it is supposed to be the only belonging Eben wants to be identified with. In this case, if it is closely observed, the farm stands for the mother image to Eben, who loves the farm as ardently as he loves his mother.

So, the question arises, who he is heir to for the farm he claims as O'Neil portrays Eben saying "I'm Maw- every drop o' blood!" (O’Neil 322). Logically enough, Eben is a biologically Ephraim's son, but is more attached to his mother embodying all her loving nature, and selfless love unlike the other Cabots. He saw his mother working everywhere in the farm when she was alive. Even after her death, he also sees her mother roaming in the farm in the form of a ghost in front of him. Her presence gives him a sense of belonging to the farm, and also makes sense for him to live. Thus his sensing belongingness to the farm helps him associating with his mother. To him, to possess the farm is to get associated with his mother, and her love again. He gets severely guilt-driven a person that he is torn between his wish to avenge his father, and his failure not being able to accomplish. However, one day he explores a way to win in his first mission. He has known the place, where his father deposits money. He realizes that the only thing he can do is to purchase his brothers' share of the farm, because his brothers need money to go to California for gold. They have decided to leave because the stone walls, they are surrounded by, sense a life of imprisonment to them. So, finally, Eben succeeds in his mission to claim his full right to the farm. 
In addition, it is noted that the technique he applies to own the two other Cabots' share manifests his criminal act for a solution. From a psychoanalytic perspective, Eben turns a guilt-driven man, who seeing no other way, has motivated his brothers to leave their share for the money. Freud explains in The Ego and the Id that "it came as a surprise to discover that an intensification of this unconscious guilt-feeling can turn a person into a criminal- but this is undoubtedly the case" (Freud 142).

Moreover, in Beyond the Pleasure Principle and Other Writings, Freud is understood to have observed that "in many criminals, especially juveniles, we find clear evidence of a powerful guilt-feeling that was already in existence before their criminal act, and thus was not a consequence of it but rather the impetus behind it, as if they found it a relief being able to tie this unconscious guilt-feeling to something concrete and immediate" (Freud 142). Freud also adds that "paradoxical as it may sound, I must maintain that the sense of guilt was present before the misdeed, that it did not arise from it, but conversely- the misdeed arose from the sense of guilt. These people might justly be described as criminals from a sense of guilt" (Freud 317). When Eben succeeds in becoming the competitor for the farm to possess, he celebrates the victory over his father's absence. He feels that the farm is now under his possession. He expresses his feeling of happiness by shouting "it's purty! It's damned purty! It's mine! (He suddenly throw his head back boldly and glares with hard, defiant eyes at the sky) Mine, d'ye hear! Mine!" (O'Neill 21). He then looks at the farm, and it's beauty with all his fondness for the farm, and emotional attachment. He becomes so overwhelmed as if he has physically reconciled with his mother, and became rejuvenated again. Studying Carl Jung's Symbols of Transformation, the Cabot farmhouse is traced having a greater significance. To Jung's scholarship, Eben getting closer to the farmhouse is his getting closer to "the origin in the sense of the mother. It represents the source of life, of that magical life force" (Jung 258) .

The sense of possession of the farm has pacified his death drive. He sees that there is no one in the farmhouse except him. From the Freudian perspective, Eben is observed to have taken his father's right to his mother, and owns her mother. Freud explains it as being "a straightforward sexual object-cathexis towards his mother, and an identification with his father to take him as his model" (Freud 175). After Eben removes his brothers, and takes the their share of the farm, Eben becomes equal to his father, and then takes the role of his father representing that Eben's mother is now under his possession. Eben's possession of the farm as well as his emotional attachment with his mother clearly manifest his unification with his mother. Freud adds that "the little boy notices that his father stands in his way with his mother. His identification with his father then takes on a hostile coloring and becomes identical with the wish to replace his father in regard to his mother as well" (Freud 175). The hostility between them is evident in Ephraim's constant referring Eben to a soft and lovingseeking boy, but meaning his unmanliness. Therefore, the love, and emotional bond which he is used to demand is only from his mother.

Like every baby, Eben's emotional bond with his mother started with his mother's breast, but after her death, the farm symbolically replaces his mother's breast, and becomes his object choice. In his analysis of objectcathexis, Freud says that "at a very early age he [the male child] develops an object-cathexis in respect of his mother" (122). He furthers the idea that the male child's starting point is "mother's breast" and "which constitutes a paradigmatic example of the imitative type of object-choice" (Freud 122). However, the union of Eben's possession of the farm, and his emotional bond with his mother does not last long. To his bewilderment, his father comes back from exile with his newly, and third wife named Abbie Putnam. Eben starts feeling a sense of negativity regarding the ownership of the farm, though, for some moments ago, he thought that he avenged his father. Eben fears that his step-mother shall claim the farm, which he has just taken hold of. His father's remarriage makes him angry again because he thinks that the farm, which is filled in with his mother's memories, can anytime be shared by his father's new wife. When Abbie, his step-mother sees Eben, and comes close to him inquiring if he is Eben, he reacts, "(with bitter scorn) Ha! Ye kin go t' the devil” (O'Neill 29). Eben's hates for his father becomes twofold now, because his father's remarriage implies her new mother's taking full hold of 
the farmhouse, and he cannot purchase her share with the money. His mind is filled in with revengeful passion toward his father again, though, seems to be pacified by possessing of the farm, for the sudden appearance of a new step- mother.

Literally, his step- mother's presence generates a feeling of threat in his heart. Freud interprets what possibly Eben feels in his heart in that situation. He explains that in such condition, "Eros and the death drive do battle within the id" (Freud 149). According to the Freudian concept of personality, it is true that the battling for the ownership for the farmhouse from the beginning is Eben's instinctual call that has resulted in his dealing with Simeon, and Peter. At this sudden encounter, Eben's aggressive drive fails to figure out what step should be appropriate that he can take at this time. Verily, as Eben is physically attractive, he, instantly, becomes aware of the fact that Abbie, at first sight, is attracted to him sexually. For Eben, her seductive attraction triggers a unique scheme of taking a severe revenge on his father. Eben also responds to the call she makes. In this case, his revenge drive gets prompted, but in the form of love drive. Freud argues in The Ego and the Id that "we could depict the id as being entirely under the control of the mute but mighty death drives, who seek peace and, prompted by the pleasure principle, seek to pacify Eros the troublemaker- but we fear that to do so would be to underestimate the part that Eros plays" (Freud 149). Eben understands that she never marries a man of seventy for love, but for a material possession that drives her here in the Cabot house. On the other hand, Eben spares no chance to loose the hold on the farm. So, he also does not miss to arouse her sensually:

A moment later the kitchen door is slowly pushed open and Abbie enters. For a moment she stands looking at Eben. He does not notice her at first. Her eyes take him in penetratingly with a calculating appraisal of his strength as against hers. But under this her desire is dimly awakened by his youth and good looks. (O'Neil 21)

Also, to validate the authority of the house he lets Abbie know that he is the owner of the farm. He tells Abbie, "this farm- was my Maw's, damn ye!- an' mine now!" (O'Neill 30). In fact, he suggests a clear identification that he has with the farm, and that he will not let it hand over to Abbie. On his part, his mother and the farm are inseparable. Freud in An Object Relations Theory of Internal Object comments on a person's obsession of unconscious fantasies. He introduces the idea that "unconscious fantasies about objects may under certain circumstances take the place of actual relationships with people" (Freud 134). Similarly, Eben's fantasy about the farm, though it is merely an object, takes the place of his mother. From a Freudian perspective, Eben is understood to have particularized the relationship between the farm [the object] and his dead mother [the actual Being]. He idealizes that the farm, and his own mother are same. So, he does neither recognize his stepmother, Abbie to be identified with the farm nor recognizes her claiming a place of his own mother. That is why he is outraged when Abby being a second wife to his father is brought to their farm house by his father himself. Eben shows no sign of welcome; rather "appears outside, slamming the door behind him. He comes around the corner, stops on seeing his father and stands staring at him with hate" ( $0^{\prime} N$ Neill, 31$)$. His anger is realized to be so intensified that one can sum up saying that he desires to kill his father at that moment. Eben's vengeful attitude toward his father touches it's peak when he calls his father, the old whore in his conversation with Abbie. Here Eben's ultimate hate for his father inspires in Eben a violent revenge, that is, arousing lust in Abbie to take here away from his father's life. Eben notes in her eyes the same destructive desire for the farm as desired by him. So, if Abbie, and Eben become lovers, there shall be no problem for Eben with regard to the ownership of farm, but Ephraim, shall go into the lifetime imprisonment of horror. To avenge his father, Eben, finally, manifests the ultimate sickness of Oedipus' character that reflects on his possessive instinct costing destruction in its utmost.

\section{Eben's Possession of AbBiE's Love And His Completion of ReVEngE}

Eben's final scheme of taking revenge on his father results in his attempt to woe, and possess his step-mother, and drive his father facing the horrific end. From the storyline Eben's possessing of Abbie's love consists of his special motive that actually indicates two antithetical impulses in him only to resolve the problem he has with his 
father. If it is scrutinized, Abbie knows what she needs from Eben - an unabashed seeking sex in its instinctual form. On the other end, Eben's affair with Abbie hints no love, but implying a conscious despises reserved for his father. The only ideal self Eben recognizes for himself with is his dead mother's. O'Neil's application of his naturalistic ethics explains the love is a natural call, but the responds from the other side can only be motives for varied accomplishments. Eben wants to possess his new mother is merely a motive that describes little significance about true passions, and significance. To possess his step-mother means the possession of her love, and thus the possession of the pains reserved to inflict upon his loathed father. Accordingly, Eben plans to enter into a sexual intercourse with his step-mother to complete his revenge on his father. Eben's plan to make erotic relationship with his step-mother can be analyzed in the light of the psychoanalytic criticism. Freud argues that the son's erotic relationship with his mother is 'mother complex'. It was a concept that was first developed by Freud himself. He elaborated the concept by identifying that the male child has an illusion, and also fantasizes about his mother, that is to say, the male child shows a close emotional or sexual tie with his mother. Michael Billig also argues in Oedipal Desires and Oedipal Parents that "in his imagination the son becomes the father: if he were the father, then he would be able to possess the mother" (Billig 106). The play, however, delineates in a detailed description how the sexual intercourse takes place between Eben and his step-mother.

The play describes that "they kiss in restrained fashion. Then suddenly wild passion overcomes her. She kisses him lustfully again and again and he flings his arms about her and returns her kisses (O'Neill 47) and "throws himself on his knees beside the sofa and grabs her in his arms-releasing all his pent-up passion" (O'Neill 48). Eben's release of passion for his step-mother in their intimate moment can be argued to have prefigured that he centers his sexual desire on his stepmother, and germinates antagonistic impulse toward his father. In Eben's case, the moment he enters into Abbie, it breaks the stone walls bearing symbols to the character of Ephraim, and signifies the satisfaction by thinking his father's loss of a close kin similar to himself. This is a complex revenge plan by possessing his new mother, which leaves his father with unbearable shame, and utter punishment. His father becomes almost mad, and suffers a traumatic shock to know that his new wife, Abbie does not love him, but Eben. She discloses to her husband that the baby she conceives is also Eben's not his. The basic motivation Ephraim finds in Abbie by marrying her is gone upon hearing the hidden passion she cherishes for his son. The sense of completeness what Ephraim boasts of is viciously shattered when Abbie, as a proof of her true love for Eben, smothers her baby in the cradle. She claims that she kills her baby because she loves Eben, and does not want the baby to be the heir that it can claim the farm from Eben before him. However, the play details the scene when Ephraim Cabot tries to come close to Abbie and inquires about the baby. She replies with rage and hatred as she:

Gives him a furious push which sends him staggering back and springs to her feet--with wild rage and hatred. Don't ye dare tech me! What right hev ye t' question me 'bout him? He wa'n't yewr son! Think I'd have a son by yew? I'd die fust! I hate the sight o' ye an' allus did! Its yew I should'hv murdered, if I'd had good sense! I hate ye! I love Eben. I did from the fust. An' he was Eben's son-mine an' Eben's-not your'n!. (O'Neill 49)

Once the man, who turned the stone land into a living place with all of his vigor, strength, glory, determination, honor, and success is thoroughly robbed off by his son, Eben. Added that, the woman Ephraim marries, and brings in his house to get rid of his lonesomeness has literally helped to fix his lonesomeness forever. This happens due to her sexual passion that has destroyed Ephraim's life, and driven herself to Eben. For her own insatiable sexual attraction, the trap she fixes for Eben, ultimately, finds herself in and Ephraim remains in perplexity. Barrett H. Clark in Eugene O'Neill: The Man and His Plays mentions:

In arousing the repressed passion of Eben she has forgotten, or perhaps never known, that the sex instinct cannot easily be controlled; she has depended on her own craftiness to see her machinations through in cold blood to the end. Then suddenly she finds herself caught in her own trap. (152) 
Love and Revenge of Eben in Desire under the Elms: A Psychoanalytic Reading

This is how Eben has taken his revenge on his father ultimately with so much aggression that brings no difference for his father even though he is left alive in the Cabot house.

\section{CONCLUSION}

The paper, however, has focused on the protagonist Eben Cabot's two internal drives - the love drive and of the revenge drive. It has discussed his drives with paying a critical attention to the theory of psychoanalysis. The play delineates that Eben was attached to his mother very closely, and upon loosing her, he madly accuses his father of her death because he believes that his father kills her. The essay has discussed the theme of love, and of revenge how Eben Cabot makes a perfect plan to avenge his father. He has schemed a plan to punish his father severely and, at the end, succeeded in his plan. Particularly, at first, Eben has seduced Minnie, the village prostitute with whom Eben's father has physical contact. Then Eben has persuaded his two elder brothers to leave their share to him for the golds offered to them. Eben takes his last revenge on his father seducing his stepmother, Abbie. His father suffers greatly when he comes to know that Abbie loves Eben, and Eben was Abbie's baby's father, and cries to hear that Abbie smothers it in the cradle. To sum up, Eben makes himself a successful avenger, who spares his father to what he is afraid of - lonesomeness. Eben does not kill his father in the way the son kills his primal father, but breaks him psychologically, and emotionally by inflicting on him intense pain, and horror. His father remains loveless as he is supposed to be, and also the most despised a person to Eben. Eben's aggression leaves his father without anyone he can talk with or any company he can keep with. His father himself expresses that he becomes lonelier than he was before. He stares in horror that all of his family members leave him.

\section{REFERENCES}

1. Billig, Michael. Freudian Repression: Conversation Creating the Unconscious. Cambridge University Press, 1999.

2. Clark, Barrett H. Eugene O'Neill: The Man and His Plays. Robert M. McBride \& Company, 1929.

3. Freud, Sigmund. Beyond the Pleasure Principle and Other Writings. Penguin Books, 2003.

4. Freud, Sigmund. "Internal Object Relations." In The Matrix of the Mind, edited by Thomas H. Ogden, Jason Aronson Inc, 1990, pp. 131-165.

5. Freud, Sigmund. Art and Literature. Penguin Books, 1990.

6. Freud, Sigmund. "Beyond the Pleasure Principle" In Literary Theory: An Anthology, edited by Julie Rivkin and Michael Ryan, Blackwell, 2000, pp. 168-174.

7. Freud, Sigmund. "Beyond the Pleasure Principle" In Literary Theory: An Anthology, edited by Julie Rivkin and Michael Ryan, Blackwell, 2000. pp. 175-177.

8. Freud, Sigmund. Totem and Taboo. Routledge paperback, 1983.

9. Fromm, Erich. The Revision of Psychoanalysis. Westview press, 1992.

10. Gassner, John. Eugene O'Neill- American Writers 45: University of Minnesota Pamphlets on American No. 45. University of Minnesota Press, 1965.

11. Gaylin, Willard. Hatred. Public Affairs, 2003.

12. Levine, Michael P. Analytic Freud: Philosophy and Psychoanalysis. Routledge, 1999. 
Love and Revenge of Eben in Desire under the Elms: A Psychoanalytic Reading

13. O'Neill, Eugene. Desire under the Elms and The Hairy Ape. Random House, 1959.

14. Falk, Doris V. Eugene O'Neill and the Tragic Tension. Rutgers University Press, 1958.

15. Raleigh, John Henry. The Plays of Eugene O'Neill. Southern Illinois University Press, 1965.

16. Bogard, Travis, editor. O’Neill, Eugene. Eugene O’Neill: Complete Plays 1932 -1943. 1st ed.,The Library of America, 1988.

17. Jung, Carl. Symbols of Transformation. Princeton University Press, 1956.

18. O'Neill, Eugene. Three Plays: Desire Under the Elms, Strange Interlude, Mourning Becomes Electra. Vintage Books, 1995.

Citation: A.K.M. Aminur Rashid, "Love and Revenge of Eben in Desire under the Elms: A Psychoanalytic Reading" American Research Journal of English and Literature, vol 4, no. 1, 2018, pp. 1-11.

Copyright (c) 2018 A.K.M. Aminur Rashid, This is an open access article distributed under the Creative Commons Attribution License, which permits unrestricted use, distribution, and reproduction in any medium, provided the original work is properly cited. 